
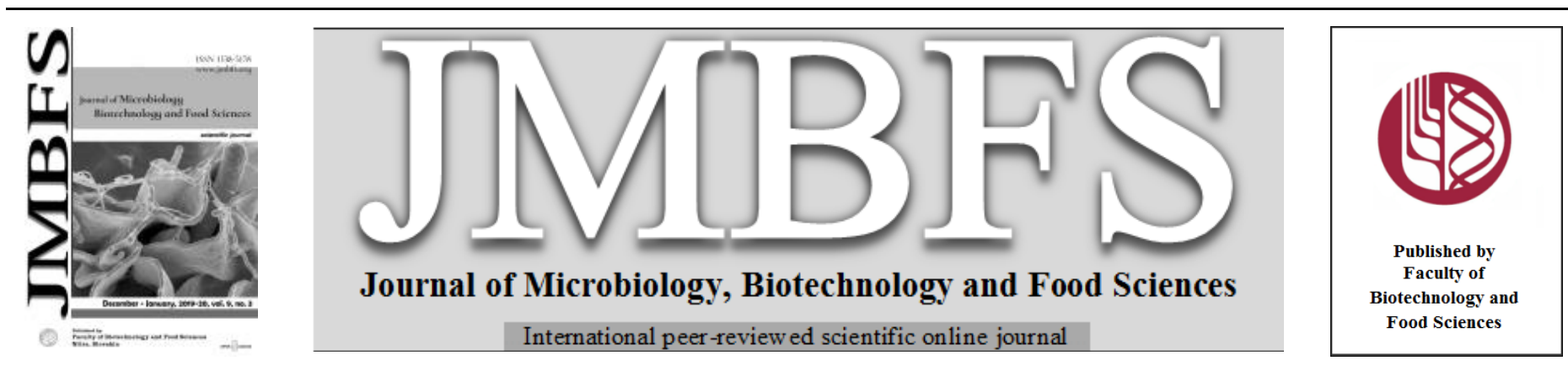

\title{
ACRYLAMIDE INFLUENCE ON THE ACTIVITY OF CHOLINESTERASES, OXIDATIVE STRESS MARKERS, CASPASE-3 EXPRESSION AND MICROSTRUCTURE OF THE FOREBRAIN OF CHICKEN EMBRYOS
}

\author{
Marta Batoryna *1, Agnieszka Leśniak ${ }^{2}$, Marta Kopańska ${ }^{3}$, Grzegorz Formicki ${ }^{1}$ \\ Address(es): Marta Batoryna, \\ ${ }^{1}$ Pedagogical University of Cracow, Institute of Biology, Department of Animal Physiology and Toxicology, Podbrzezie 3, 31-054 Kraków, +48 1266266922 : \\ ${ }^{2}$ University of Agriculture in Krakow, Faculty of Animal Science, Department of Animal Physiology and Endocrinology, Al. Mickiewicza 24/28, 30-059 Kraków. \\ ${ }^{3}$ University of Rzeszow, Faculty of Medicine, Department of Human Physiology, Al. Kopisto 2a, 35-959 Rzeszów.
}

*Corresponding author: m.batoryna@gmail.com

doi: $10.15414 / j m b f s .2019 / 20.9 .3 .643-647$

ARTICLE INFO

Received 15. 5. 2019

Revised 4. 8. 2019

Accepted 9. 9. 2019

Published 1. 12. 2019

Regular article

open $\partial_{\text {ACCESS }}$

\begin{abstract}
The aim of this study was to examine the influence of acrylamide (ACR), a common neurotoxin, on the neuroepithelial cells utilizing in ovo model for embryonic brain development. On day five (E5), 75 eggs with living embryos were randomly divided into three groups: one control and two experimental ( $\mathrm{n}=25)$ and injected with $0.7 \% \mathrm{NaCl}$ and/or ACR saline solution at the dose of $30 \mu \mathrm{g}$ or $300 \mu \mathrm{g}$ per egg , respectively. The injections were performed directly into the amniotic fluid, and after $7 \mathrm{~h}$ of incubation, tissues the brain was collected Additionally, for the brain microstructure evaluation brain tissues were obtained from $10^{\text {th }}$ day embryos. Immunohistochemical localization of caspase-3 and histochemical staining demonstrated deterioration and significant damage to neuroepithelial cells and affected caspase-3 distribution/expression in brain. Results of biochemical assays showed increased activity of enzymes (SOD, AChE, BuChE) whereas ACR had no impact on the MDA concentration. This suggests that ACR has no direct impact on the caspases, and its action is an effect of SOD response to free radicals probably. ACR has an impact on the activity of cholinergic nerves and brain cytoarchitecture of the developing embryos. All of the observed effects suggests serious influence of ACR on the developing brain by several different mechanisms.
\end{abstract}

Keywords: acrylamide, neuroepithelial cells, , oxidative stress, caspase-3, brain, microstructure

\section{INTRODUCTION}

Acrylamide (ACR) and its polymer- polyacrylamide, are broadly applied in laboratories and industrial processes. The polymeric form is relatively non-toxic, whereas its electrophilic monomer has been reported to pose adverse effects. The potential risk to the ACR exposure is due to the prevalence of this toxin in carbohydrate-rich processed food, tobacco smoke and occupational exposure (Smith et al., 2000). Accumulating evidence suggested that ACR induces a high risk of neuropathic alteration in humans and animals (Friedman, 2003; Riboldi et al., 2014). Acrylamide also occurs in animal feeds and can be carried over to food of animal origin. It was shown that acrylamide may enter the animal feed chain via by-products from the food industry such as biscuits, bread, crispbread, potato products, waffles and other heated by-products (Halle et al., 2006) Electrophilic properties, allow ACR to cross the biological barriers (Von Stedingk et al., 2011; Duarte-Salles et al., 2013).

Previous studies indicate that ACR influences human astrocytoma cells and nerve terminal degeneration of the central nervous system (Yu et al., 2005; Chen et al., 2013). ACR also has an impact on the cholinergic system. It was found that ACR enhanced the activity of the acetylcholinesterase (AChE) in peripheral nerves (Pennisi et al., 2013). Another study indicated declined activity of AChE in the mice brain after ACR administration (Kopańska et al., 2015). Furthermore, ACR is known to promote the induction of reactive oxygen species and depletion in anti-oxidant rates which may then lead to the neurodegenerative conditions including neuronal apoptosis of the cerebral cortex (Lopachin and Gavin 2008; Lakshmi et al., 2012; Batoryna et al., 2017).

However, little is known about its influence on the development of the neural system in animal embryos. Taking the above into consideration, our study has been focusing on the ACR impact on the neuroepithelial (NE) cells, which undergo intensive proliferation in order to produce more progenitor, neuronal and macroglial cells within the central nervous system. To recognize the possible mechanism of ACR toxicity in the brain of animal embryos, we have performed measurements of antioxidative enzymes activity, cholinesterases activity, and analysis of caspase-3 expression. In ovo model has been chosen as a well- recognized and suitable model for animal embryo development studies (Stern, 2005).

\section{MATERIAL AND METHODS}

\section{Animals and acrylamide treatment}

75 fertilized hen eggs, weight $62.70 \pm 6.11 \mathrm{~g}( \pm \mathrm{SD})$, from the commercial broiler breed parental flock of Ross 308 line, were incubated at $37.5 \pm 0.5{ }^{\circ} \mathrm{C}( \pm \mathrm{SD})$ with 55\% humidity within 5 days. On day five (E5) 75 eggs with the living embryos were divided into three groups (one control and two experimental). Next, the eggs were candled for the embryo localization. After that, window

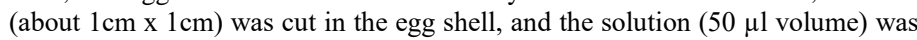
injected across the chorioallantoic membrane into the amniotic fluid. Next the windows in the egg shells were covered with Parafilm ${ }^{\circledR} \mathrm{M}$, and the eggs were incubated for seven hours. Experimental groups (25 eggs each) were injected with $30 \mu \mathrm{g}$ or $300 \mu \mathrm{g}$ of ACR per egg dissolved in $0.7 \% \mathrm{NaCl}$. Control group of 25 eggs was injected with $0.7 \% \mathrm{NaCl}$.

A study performed by Sörgel et al. (2002) showed that the half-life of acrylamide in the human body is 2-7 hours. The used procedure of injections of chick embryos was proposed by (Johnston et al., 1997; Dong et al., 2014). After seven hours incubation, embryos were dissected, fixed in freshly prepared $4 \%$ $(\mathrm{v} / \mathrm{v})$ buffered $(0.1 \mathrm{M}$ phosphate buffer, $\mathrm{pH}=7.6)$ formalin or immediately frozen and stored at $-80^{\circ} \mathrm{C}$ until further analysis. Additionally, to observe the effect of ACR on the brain microstructure changes, part of the embryos (5 from each group) were left for the development until tenth day (10E), embryos were dissected and fixed in freshly prepared $4 \%(\mathrm{v} / \mathrm{v})$ buffered formalin.

The experiment was carried out in accordance with the provisions of the National Ethical Committee for Animal Experiments.

\section{Biochemical assay}

Biochemical analyses were performed on the 12 embryos $(n=12)$ from each group (after 7 hours administration). 


\section{Superoxide dismutase activity}

The analysis of superoxide dismutase (SOD) activity was assayed according to the method described by Kono (1978) and Rice-Evans et al., (1991). The assay is based on the inhibiting influence of SOD on the reduction of cytochrome $\mathrm{C}$ by the superoxide anion, which is generated by xanthine/xanthine oxidase. The tissues were homogenized in ice-cold $100 \mathrm{mM}$ potassium phosphate buffer $(\mathrm{pH}$ 7.0). The absorbance was measured at $\lambda=550 \mathrm{~nm}$ for 120 seconds using the MARCEL S330 spectrophotometer (Marcel, Poland). The results were presented as $\mathrm{U} / \mathrm{mg}$ protein.

\section{General protein concentration}

General protein concentration was determined using the Bradford's method (1976). The absorption spectrum for dye in acidic solution is at $465 \mathrm{~nm}$ and after the protein binding, the maximum moves towards longer wavelengths and occurs at $595 \mathrm{~nm}$. The calibration curve was prepared with bovine albumin (BSA) in the range of protein concentration of $0.1-1.4 \mathrm{mg} / \mathrm{mL}$. The measurement was performed by using the microplate reader (TECAN Sunrise) at wavelength $\lambda=$ $595 \mathrm{~nm}$.

\section{Malondialdehyde concentration}

The concentration of the malondialdehyde (MDA) was determined according to Ohkawa (1979). The double-heating method based on the reaction of thiobarbituric acid (TBA) with MDA was used The tissues (1mg) were homogenized in the homogenizer (CAT X360) with $10 \mathrm{ml}$ of RIPA buffer (cell lysis solution reagent) containing $0.1 \% \mathrm{v} / \mathrm{v}$ protease inhibitor. After centrifugation (4500rpm), sodium dodecyl sulfate (SDS), trichloroacetic acid (TCA), and TBA were added to the sample and boiled. Next, the sample was cooled, centrifuged and the supernatant was placed on the microplate reader TECAN to measure the absorbance at $\lambda=535 \mathrm{~nm}$ with respect to the blank solution. The results are presented as $\mu \mathrm{M} / \mathrm{mg}$ tissue.

Acetylcholinesterase (AChE) and butyrylcholinesterase (BuChE) activities

For $\mathrm{AChE}$ and $\mathrm{BuChE}$ measurements brain tissues were homogenized in ice cooled $\left(4^{\circ} \mathrm{C}\right) 0.1 \mathrm{M}$ sodium phosphate buffer $(\mathrm{pH}=8)$ in the proportion of $1 \mathrm{ml}$ buffer per $20 \mathrm{mg}$ of the tissue. The supernatant obtained after centrifugation of tissue homogenate was used to measure acetylcholinesterase and butyrylcholinesterase by the Ellman's (1961) colorimetric procedures. The method base on the hydrolysis of acetylthiocholine or butyryltiocholine iodide, where the final product is thiocholine. Thiocholine in the presence of the highly reactive dithiobis-2-nitro-benzoic acid (DTNB) reacts to generate the yellow 5thio-2-nitrobenzoate product. The absorbance was measured at $\lambda=412 \mathrm{~nm}$ after 60 seconds. The results were presented as $\mu \mathrm{M}$ of acetylthiocholine or butyryltiocholine iodide per $\mathrm{g}$ tissue/h. Detection was performed with a MARCEL S330 spectrophotometer.

\section{Histochemical Preparation}

Sections were prepared from the whole body of the embryo. The detailed microscopic analyses were perfomed in the forebrain. Five microtome sections from five embryos form each group ( 7 hours ACR administration), $n=5,(5 \mu \mathrm{m}$ thick) were deparaffinized, rehydrated and submitted to hematoxyline or DAPI (4', 6-diamidino-2-phenyl-indole) staining procedure. Immunohistochemica localization of caspase- 3 was performed after incubation in citric buffer $(\mathrm{pH}=6.0$, $75^{\circ} \mathrm{C}$ ) and quenching endogenous peroxidase activity with $3 \% \mathrm{H}_{2} \mathrm{O}_{2}$ solution in methanol. Nonspecific binding of the secondary antibody was blocked with $5 \%$ (v/v) normal goat serum in TBST (RT). Sections were then incubated with primary rabbit polyclonal antibody against caspase-3 $(1: 300)$ for $12 \mathrm{~h}$ at $4^{\circ} \mathrm{C}$, followed by biotinylated goat anti-rabbit antibody (RT) and avidin-biotinhorseradish peroxidase complex. Colour reaction was developed using diaminobenzidine (DAB) and $\mathrm{H}_{2} \mathrm{O}_{2}$ solution. Light/fluorescent microscope (Nikon AZ-100 with light NIS ELEMENTS AR) and ImageJ software (version 2.0.0-rc-43/1.51p) were utilized to calculate the ratio of caspase-3-positive cells Each slide was examined in five random areas. To estimate ACR effects on the further brain development brain tissues of embryos exposed to ACR up to E10 were dissected to perform hematoxylin and eosin staining according to Fisher $\boldsymbol{e t}$ al., (2008).

\section{Experimental Materials}

The primary rabbit polyclonal antibody against caspase-3 (1:300), biotinylated goat anti-rabbit antibody (RT), avidin-biotin-horseradish peroxidase complex and diaminobenzidine were obtained from Abcam (Cambridge, UK). Reagents for superoxide dismutase (SOD), malondialdehyde (MDA), acetylcholinesterase (AChE) and butyrylcholinesterase (BuChE) measurements, cytochrome C, xanthine oxidase, thiobarbituric acid, protease inhibitor, radioimmunoprecipitation assay buffer (RIPA), sodium dodecyl sulfate (SDS), acetylthiocholine iodide, butyryltiocholine iodide, DTNB (Ellman reagent) were supplied by Sigma Aldrich (Saint Louis, Missouri, USA), hematoxylin (Stamar, Poland) and eosin (Stamar, Poland).

\section{Statistical analysis}

The dependent variables were checked for their distribution and homogeneity using Shapiro-Wilk and Levene tests respectively. The results were compared by one-way ANOVA followed by Tukey's test. The significance level was established at $\mathrm{p}<0.05$

\section{RESULTS AND DISCUSSION}

The main protein of cholinergic synapses in the brain and neuromuscular connections is acetylcholinesterase. The function of the enzyme is to regulate the conduction of nerve impulses by fast hydrolysis of the neurotransmitter acetylcholine (Jbilo et al. 1994). The expression of the cholinergic system during embryonic development is a common occurrence. In mammals, AChE maintains high concentration during maturation and development of the placenta and the fetus. BuChE transcripts appeared before AChE transcripts early in development In chick embryos, BChE is transiently expressed during the late stages of cell proliferation, whereas AChE expression is associated with differentiating cells withdrawn from the mitotic cycle (Layer, 1990; Layer And Sporns, 1987). Kopańska et al. (2017) indicated that ACR administration resulted in a significant decrease in AChE activity in different brain structures of adult Swiss mice. In rats, ACR also diminished AChE and ATPase activity in the cerebellum of mothers and their suckling pups (Ghorbel et al., 2016). Shrivastava et al. (2018), observed significant inhibition of AChE activity in the brain after ACR administration in adult Wistar female albino rats. In contrasts, we have observed a significant increase in the activity of $\mathrm{BuChE}$ and AChE. Acetylcholinesterase (one way ANOVA $F(2,12)=23.250, \mathrm{p}<.0001$ ) and butyrylcholinesterase (one way ANOVA $F(2,12)=21.748, \mathrm{p}<.001$ ) activity was a significant increase in groups treated with ACR (Fig. 3) in comparison to the control. Different effect of ACR on cholinesterases, observed in our results, comparing to other authors, may be related to the specificity of physiological conditions in developing embryos. Moreover, in most of the research presented above, ACR total exposure were significantly higher than in our experiment. Nevertheless, our results confirm the general concept that disturbances of synapse functioning underlies the mechanism of ACR neurotoxicity. Increased activity of cholinesterases may have a significant influence on the brain of animal embryos. Cochard and Coltey (1983) demonstrated that cholinesterase activity, was present at all axial levels in presumptive crest cells of the neural folds, soon after closure of the neural tube. Furthermore, AChE plays a crucial role during early vertebrate development, in the example; neuromuscular development (Behra et al., 2002), cell differentiation and network formation, early embryonic (limb) development (Layer at al., 2013).

Other proposed mechanism of ACR neurotoxicity is associated with oxidative damage (Lopachin and Lehning, 1994). One of the defense mechanisms against free radicals is a triad of antioxidant enzymes, including superoxide dismutase, glutathione peroxidase, and catalase (CAT). SOD catalyzes the dismutation of the superoxide anion to the hydrogen peroxide which is decomposed to water and oxygen by other enzymes (Meister, 1998). Redox imbalance is detrimental to neurons due to the large concentrations of unsaturated fatty acids in neuronal membranes. Therefore, neurons are the first cells affected by free radicals in the brain (Kałużna-Czaplińska et $\boldsymbol{a l}$., 2008). To estimate the oxidative damage, we measured MDA concentrations, a secondary product which is used as convenient marker for lipid peroxidation (Ayala et al., 2014). No differences in MDA concentration (Fig. 2), observed in our studies, suggest that the damage of neuroepithelial cells was not related with lipids peroxidation. Moreover, increased SOD activity (One way ANOVA $F(2,18)=5.4961, \mathrm{p}<.05$, Fig. 1 ) accompanied by higher AChE and BuChE activity could also have an impact on MDA level, because of the effective protection against oxidative stress by these enzymes (Liu et al., 2001). However, the distinctiveness between our results and the results of other research might have been caused by the diverse periods of ontogenesis, low doses of ACR and short time of exposure to ACR in our research. High activity of SOD and no symptoms of lipids peroxidation, may suggest a genotoxic mechanism of ACR influence on the neuroepithelium. This could be associated with the immense genotoxic properties of the ACR metabolite - glycidamide and its ability to create adducts with hemoglobin and DNA (Lopachin and Gavin, 2012; De Lima et al., 2016) - although this is only a hypothesis and needs further research.

During the development and maturation of the nervous system, a significant amount of neuron cells of the original population undergo apoptosis. Genetically programmed death, through the selection of the neuron cells, leads to the death of almost half of them. (Yakovlev et al., 2001). In chickens, neuronal cell death affects differentiated ganglion cells with a peak at approximately embryonic day tenth (E10). In the earlier distinct phase of development, apoptosis occurs with a peak at approximately E5 and affects cells other than fully differentiated neurons (De La Rosa and De Pablo, 2000). For that reason, in our study, embryos were treated on day five of development. Apoptosis is initiated by the activation of a cascade of caspases. Apoptosome, the multiprotein complex between apoptotic 
protease-activating factor 1 (Apaf-1) and cytochrome c (CytC) is responsible for the autocatalytic activation of an initiator caspase- 9 which activates executioner caspase-3 (Chai and Shi, 2013). Caspase-3 appears to be the major executioner caspase involved in the brain neuronal apoptosis. Suppression or stimulation of apoptotic capability is essential to normal brain development (Porter and Jänicke, 1999). In our results, the antibodies specific for caspases-3 were detected in all samples. The calculation using ImageJ software and statistical analyses has shown that there were statistically significant differences in expression of caspase- 3 between control and experimental groups (One way ANOVA $F(2,26)=19.896$, p <0001). After ACR administration the number of caspase-3 positive cells substantially decreased (Fig. 4). In control embryos (Fig. $5 \mathrm{~A}$ ), caspase- 3 was evenly distributed throughout all the layers of neuroepithelia cells, whereas in embryos exposed to ACR (Fig. 5B, 5C) the enzyme positive cells concentrated in the mantle layer of the forebrain vesicle. Similarly, to our results, in vitro studies carried out on rat primary astrocytes and human astrocytoma cell lines showed decreased expression of procaspase- $3,-8$, and -9 after exposure to ACR (Lee et al., 2014). Although, in most previous studies, acceleration of the apoptotic processes, driven by ACR intoxication was observed (Sumizawa and Igisu 2007; 2009). Zhong et al., (2016) indicated that caspasedependent neuroepithelial cell apoptosis enhanced by oxidative stress was reduced by superoxide dismutase overexpression. In addition, Sugawara $\boldsymbol{e t}$ al. (2002) indicated that the overexpression of SOD reduced oxidative stress, thereby attenuated the mitochondrial release of cytochrome $\mathrm{C}$ and second mitochondria-derived activator of caspases, which resulted in a lower expression of caspases and consequently diminished rate of apoptosis. In our studies inhibition of caspases at E5 resulted in increased number of neural cells in brain hemispheres at E10, which points to the disturbances in the selection of the neuron cells in embryos exposed to ACR (Fig. 6A, 6B). Similar relation between superoxide dismutase activity and caspases was indicated in the brain of ischemic adult mice and in human umbilical vein endothelial cells (Dimmeler et al., 1999, Noshita et al., 2001). Thus, it seems that in our research the attenuated caspase- 3 activity could be associated with the enhanced activity of SOD. It is also reasonable to suggest that increased SOD activity resulted from the higher rate of superoxide anion formation in brains of embryos exposed to ACR (Fukai and Ushio-Fukai, 2011). Moreover, Kim et al., (2008) observed that AChE inhibited activation of caspase- 3 in hypoxia and the same effect we observed in our results We have also observed large extracellular intervals/spaces as well as a loss of intermitotic neuroepithelial cells and neuroblasts in the external zone of the mantle layer of the forebrain vesicle (Fig. 5G). Numerous cells with fragmented and pyknotic nuclear material were evident. At the dose of $300 \mu \mathrm{g} / \mathrm{egg}$ (Fig. 5H), larger extracellular intervals were noted, (Fig. 5E, 5F) in addition to a massive loss of neuroblasts and intermitotic neuroepithelial cells. Moreover, swollen cells in the wall of the forebrain vesicle were observed. Our study manifested prevalent pyknotic nuclei in both experimental groups (Fig. 5G, 5H) in comparison to control group (Fig. 5F). Additionally, in the present study occurrence of macrophages in the proximity of the external limiting membrane was observed (Fig. 5G). These results confirm the observations of the neuronal structure damage after ACR intoxication, indicated by Zhang et al., (2017).

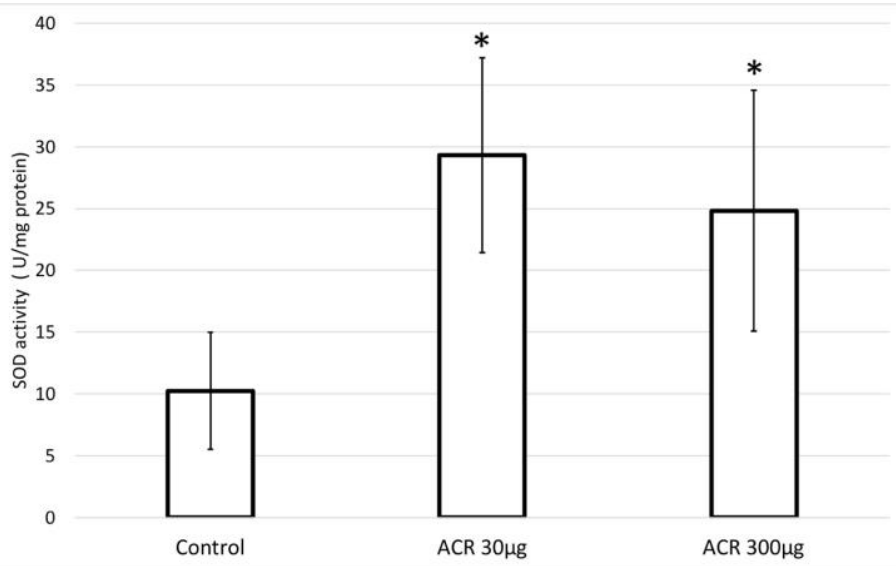

Figure 1 The influence of in ovo ACR application on the SOD activity (U/mg protein) in the 5-day old chicken embryo forming brain. Difference significant in comparison to control at $\mathrm{p}<0.05(*)$,. Bars represent mean value of SOD activity. Vertical lines indicate standart deviation ranges (SD).

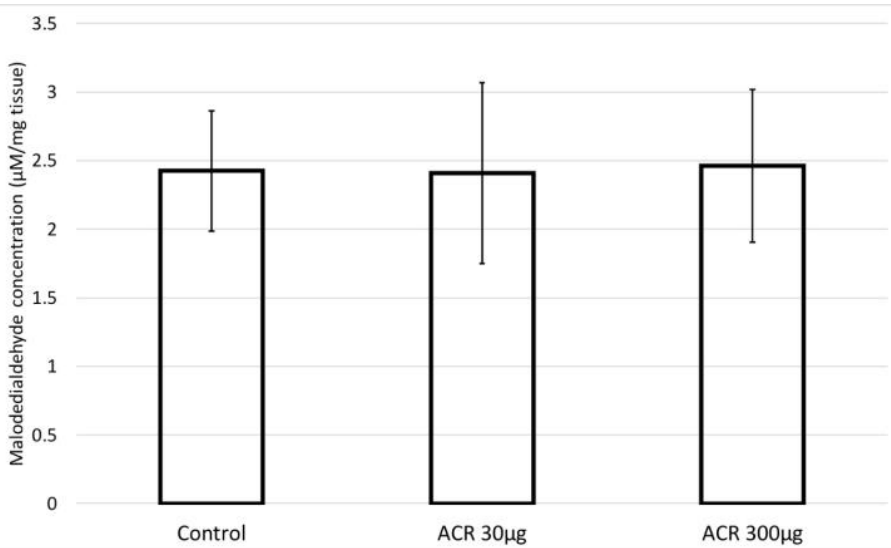

Figure 2 The influence of in ovo ACR application on the MDA concentration in the 5-day old chicken embryo forming brain ( $\mu \mathrm{M} / \mathrm{mg}$ tissue). There was no statistical differences beetwen groups. Bars represent mean value of MDA concentration. Vertical lines indicate standart deviation ranges (SD).

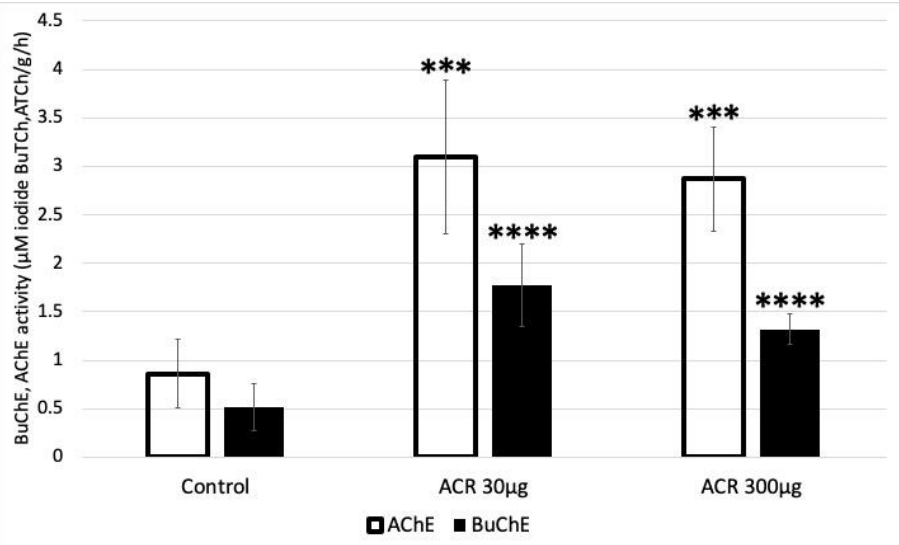

Figure 3 The influence of in ovo ACR application on the cholinesterases AChE and $\mathrm{BuChE}$ activities $(\mu \mathrm{M}$ iodide ATCh, BuChE/g/h). Difference significant in comparison to control at $\mathrm{p}<0.05$ (*), $\mathrm{p}<0.01(* *), \mathrm{p}<0.001(* * *), \mathrm{p}<0.0001$ (****) Bars represent mean value of $\mathrm{AChE}$ and BuChE activity. Vertical lines indicate standart deviation ranges (SD).

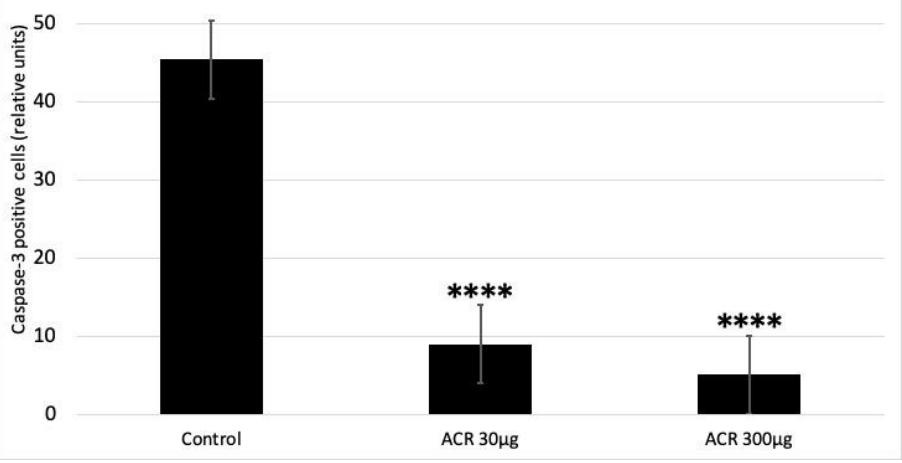

Figure 4 The influence of in ovo ACR application on the number of caspase-3 positive grains in the 5-day old chicken embryo forming brain (relative units) Difference significant in comparison to control at $\mathrm{p}<0.05\left(^{*}\right), \mathrm{p}<0.01(* *)$, $\mathrm{p}<0.001(* * *), \mathrm{p}<0.0001(* * * *)$. Bars represent mean value of caspase-3 postive cells. Vertical lines indicate standart deviation ranges (SD). 

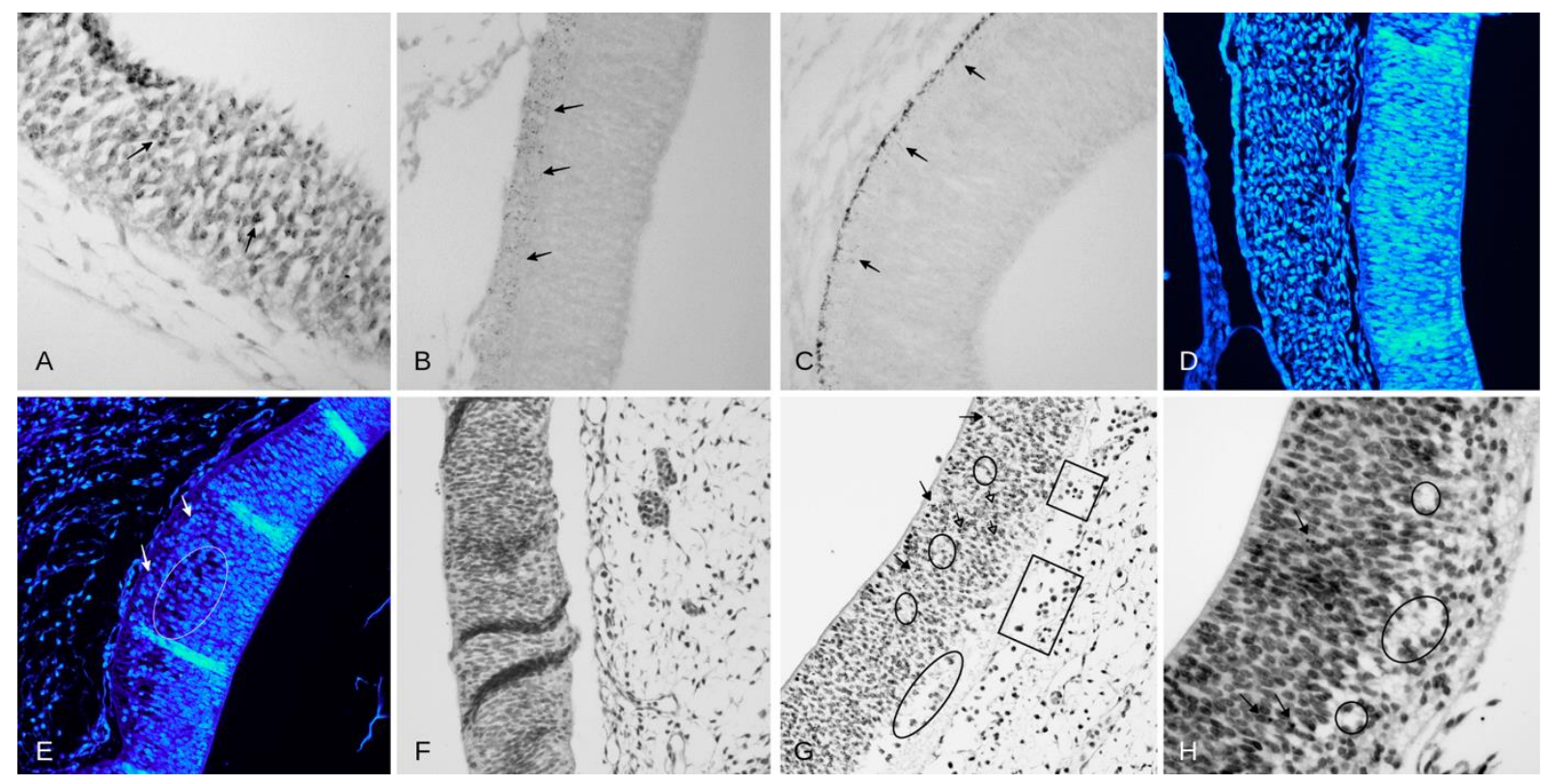

Figure 5 The effect of ACR exposure on the forming chick embryo brain. Section through wall of forebrain vesicle of the 5-day old chicken embryo

A: Control group. Immunohistochemical staining for caspases 3 (primary rabbit polyclonal antibody against caspase-3). The positively stained material is evenly distributed throughout the whole layers of cells - arrows $(\times 400)$. B: ACR dose of $30 \mu \mathrm{g} / \mathrm{egg}$ mass. Immunohistochemical staining for caspases-3. The positively stained material is distributed at the outer 3-4 layers of vesicle wall-arrows $(\times 200)$. C: ACR dose of $300 \mu \mathrm{g} / \mathrm{egg}$. Immunohistochemical staining for caspases 3 . The positively stained material is concentrated in large amounts in the mantle layer of cells-arrows $(\times 200)$. D: Control group. DAPI staining for nuclear material $(\times 200)$. E: ACR dose of $30 \mu \mathrm{g} / \mathrm{egg}$. DAPI staining. Massive loss of intermitotic neuroepithelial cells and neuroblasts visible in the mantle layers - ellipses. Swollen cells visible in the outermost layer - arrows $(\times 200)$. F: Control group. Staining with hematoxylin \& eosin $(\times 200)$. G: ACR dose of $30 \mu g / e g g$. Staining with hematoxylin \& eosin. Large extracellular spaces and loss of cells from mantle layer - ellipses. Pyknotic cells - full arrows. Numerous cells with vacuoles - empty arrows. Numerous macrophages, mostly located next to the external limiting membrane - rectangles $(\times 200)$. H: ACR dose of $300 \mu \mathrm{g} / \mathrm{egg}$ (E5). Staining with hematoxylin \& eosin. Massive loss of epithelial cells in central and mantle layers - ellipses. Pyknotic cells - arrows $(\times 400)$
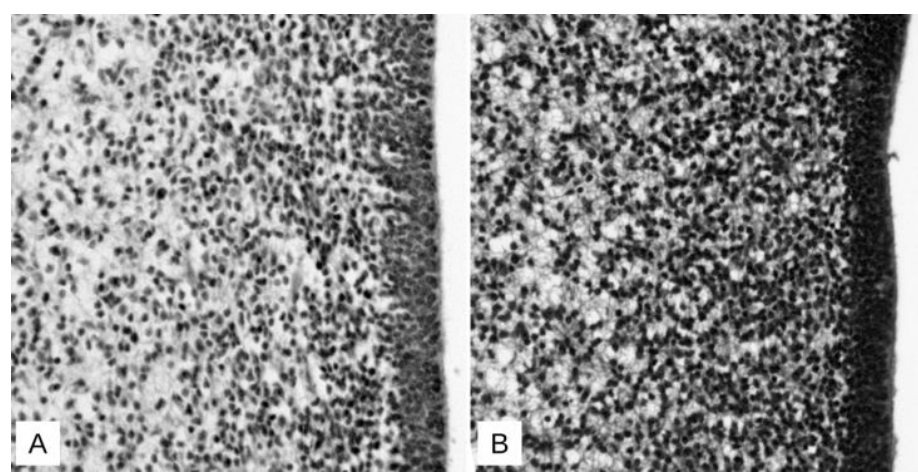

Figure 6 The cross section of the brain, left upper region brain hemisphere of the 10-day old chicken embryo.

A: Control group (E10). Staining with hematoxylin \& eosin. Free space located on the right side of the photo is the ventricle of the left hemisphere. B: ACR dose $300 \mu \mathrm{g} / \mathrm{egg}$ (E10). Staining with hematoxylin \& eosin. Increased density of neural cells visible in brain of embryos exposed to ACR in comparison with control embryos (B).

\section{CONCLUSION}

Our experiment demonstrated significant damage to neuroepithelial cells in the brain of developing embryos exposed to ACR. Taking into consideration that no differences in MDA concentrations were observed, the mechanism of the neuroepithelial cells damage seems not related with lipid peroxidation process.

The observed effects, i.e., raised deterioration of neuroepithelial cells and modified caspase-3 distribution/expression in the forming brain, may significantly influence the central nervous system development of embryos as well as their post hatch performance. It seems that ACR has no direct impact on the caspases, and its action is an effect of SOD response to free radicals generated by ACR and increased activity of cholinesterases.

\section{REFERENCES}

AYALA, A., MUÑOZ, M.F., ARGÜELLES, S. 2014. Lipid peroxidation: production, metabolism, and signaling mechanisms of malondialdehyde and 4- hydroxy-2-nonenal. Oxidative Medicine and Cellular Longevity. 360438. http://dx.doi.org/10.1155/2014/360438

BATORYNA, M., LIS, M., FORMICKI, G. 2017. Acrylamide-induced disturbance of the redox balance in the chick embryonic brain.

BEHRA, M., COUSIN, X., BERTRAND, C., VONESCH J.L., BIELLMANN, D., CHATONNET, A., STRÄHLE, U. 2002. Acetylcholinesterase is required for neuronal and muscular development in the zebrafish embryo. Nature, Neuroscience, 2, 111-118. http://dx.doi.org/10.1038/nn788

BRADFORD, M.M. 1976. A rapid and sensitive method for the quantitation of microgram quantities of protein utilizing the principle of protein-dye binding. Analytical Biochemistry, 72, 248-254.

CHAI, J., SHI, Y. 2013. Apoptosome and inflammasome: conserved machineries for caspase activation. National Science Review, 1 101-118. http://dx.doi.org/10.1093/nsr/nwt025

CHEN, J.H., YANG, C.H., WANG, Y.S., LEE, J.G., CHENG, C.H., CHOU, C.C. 2013. Acrylamide-induced mitochondria collapse and apoptosis in human astrocytoma cells. Food And Chemical Toxicology, 51, 446-52. http://dx.doi.org/10.1016/j.fct.2012.10.025

COCHARD, P., COLTEY, P. 1983. Cholinergic traits in the neural crest: acetylcholinesterase in crest cells of the chick embryo. Developmental Biology, 1, 221-38. http://dx.doi.org/10.1016/0012-1606(83)90351-2

DE LA ROSA, E.J., DE PABLO, F. 2000. Cell death in early neural development: beyond the neurotrophic theory. Trends in Neuroscience, 10, 454458. http://dx.doi.org/10.1016/S0166-2236(00)01628-3

DE LIMA, J.P., SILVA, S.N., RUEFF, J., PINGARILHO, M. 2016. Glycidamide genotoxicity modulated by Caspases genes polymorphisms. Toxicology In Vitro, 34, 123-127. http://dx.doi.org/10.1016/j.tiv.2016.03.018

DIMMELER, S., HERMANN, C., GALLE, J., ZEIHER, A.M. 1999. Upregulation of superoxide dismutase and nitric oxide synthase mediates the apoptosis-suppressive effects of shear stress on endothelial cells. Arteriosclerosis, Thrombosis, and Vascular Biology, 3, 656-64.

DONG, X.Y., WANG,Y., M. SONG, H.H., ZOU X.T. 2014. Effects of in ovo injection of carbohydrate solution on small intestine development in domestic pigeons (Columba livia). Journal of Animal Science, 91, 3742-3749 http://dx.doi.org/10.2527/jas.2013-6400

DUARTE-SALLES, T., VON STEDINGK, H., GRANUM, B., GÜTZKOW, K.B., RYDBERG, P., TÖRNQVIST, M., MENDEZ, M.A., BRUNBORG, G., BRANTSÆTER, A.L., MELTZER, H.M., ALEXANDER, J., HAUGEN, M. 2013. Dietary acrylamide intake during pregnancy and fetal growth-results from the Norwegian mother and child cohort study (MoBa). Environmental Health Perspectives, 3, 374-379. http://dx.doi.org/10.1289/ehp.1205396 
ELLMAN, G.L., COURTNEY, K.D., ANDRES, V. Jr., FEATHER-STONE, R.M. 1961. A new and rapid colorimetric determination of acetylcholinesterase activity. Biochemical Pharmacology, 7, 88-95. http://dx.doi.org/10.1016/00062952(61)90145-9

FISCHER, A.H., JACOBSON, K.A., ROSE, J., ZELLER, R. 2008. Hematoxylin and eosin staining of tissue and cell sections. CSH Protocols http://dx.doi.org/10.1101/pdb.prot4986

FRIEDMAN, M. 2003. Chemistry, biochemistry, and safety of acrylamide. Journal Of Agricultural And Food Chemistry, 51, 4504-4526. http://dx.doi.org/10.1021/jf030204+

FUKAI, T., USHIO-FUKAI, M. 2011. Superoxide dismutases: role in redox signaling, vascular function, and diseases. Antioxidants \& Redox Signaling, 6 , 1583-606. http://dx.doi.org/10.1089/ars.2011.3999

GHORBEL, I., AMARA, I.B., KTARI, N., ELWEJ, A., BOUDAWARA, O., BOUDAWARA, T., ZEGHAL, N. 2016. Aluminum and Acrylamide Disrupt Cerebellum Redox States, Cholinergic Function and Membrane-Bound ATPase in Adult Rats and Their Offspring. Biological Trace Element Research, 2, 335346. http://dx.doi.org/10.1007/s12011-016-0716-1

HALLE, L., IHLING, M., LAHRSSEN-WIEDERHOLT, M., KLAFFKE, H. FLACHOWSKY, G. 2006. Carry-over of Acrylamide from Feed (Heated Potato Product) to Eggs and Body Tissues of Laying Hens. Journal Für Verbraucherschutz und Lebensmittelsicherheit, 1, 290-293. http://dx.doi.org/10.1007/s00003-006-0050-1

JBILO, O., L'HERMITE, Y., TALESA, V., TOUTANT, J.P., CHATONNET, A 1994. Acetylcholinesterase and butyrylcholinesterase expression in adult rabbit tissues and during development. European Journal Biochemistry, 1, 115-24. http://dx.doi.org/10.1111/j.1432-1033.1994.00115.x

JOHNSTON, P.A., LIU, H., O'CONNELL, T., PHELPS, P., BLAND, M., TYCZKOWSKI, J., KEMPER, A., HARDING, T., AVAKIAN, A., HADDAD, E., WHITFILL, C., GILDERSLEEVE, R., RICKS, C.A. 1997. Applications in in ovo technology. Poultry science, 1, 165-78. http://dx.doi.org/10.1093/ps/76.1.165 KAŁUŻNA-CZAPLIŃSKA, J., GRYS, W., RYNKOWSKI, J. 2008. Neurotoxic factors in the childs environment as a reason for developmental disorders in autism. Borgis Nowa Pediatria, 3, 50-57.

KIM, M.H., KIM, M.O., HEO, J.S., KIM, J.S., HAN, H.J. 2008. Acetylcholine inhibits long-term hypoxia-induced apoptosis by suppressing the oxidative stressmediated MAPKs activation as well as regulation of Bcl-2, c-IAPs, and caspase-3 in mouse embryonic stem cells. Apoptosis, 2, 295-304. http://dx.doi.org/10.1007/s10495-007-0160-y

KONO, Y. 1978. Generation of superoxide radical during autoxidation of hydroxylamine and an assay for superoxide dismutase. Archives Of Biochemistry and Biophysics, 1, 189-95. http://dx.doi.org/10.1016/0003-9861(78)90479-4

KOPAŃSKA, M., CZECH, J., ZAGATA, P., DOBREK, L., THOR, P., FORMICKI, G. 2017. Effect of the different doses of acrylamide on acetylocholinoesterase activity, thiol groups, malondialdehyde concentrations in hypothalamus and selected muscles of mice. Journal Of Physiology and Pharmacology, 4, 565-571.

LAKSHMI, D., GOPINATH, K., JAYANTHY, G., ANJUM, S., PRAKASH, D., SUDHANDIRAN, G. 2012. Ameliorating effect of fish oil on acrylamide induced oxidative stress and neuronal apoptosis in cerebral cortex Neurochemical Research, 9, 1859-1867. http://dx.doi.org/10.1007/s11064-0120794-1

LAYER, P.G. 1990. Cholinesterases preceding major tracts in vertebrate neurogenesis. BioEssays, 12, 415 -420. http://dx.doi.org/10.1002/bies. 950120904 LAYER, P.G., KLACZINSKI, J., SALFELDER, A., SPERLING, L.E., THANGARAJ, G., TUSCHL, C., VOGEL-HÖPKER, A. 2013. Cholinesterases in development: $\mathrm{AChE}$ as a firewall to inhibit cell proliferation and support differentiation. Chemico-Biological Interactions, 1, 269-7. http://dx.doi.org/10.1016/j.cbi.2012.09.014

LAYER, P.G., SPORNS, O. 1987. Spatiotemporal relationship of embryonic cholinesterases with cell proliferation in chicken brain and eye. Proceedings of the National Academy of Sciences of the United States of America, 84, 284-288, 1987. http://dx.doi.org/10.1073/pnas.84.1.284

LEE, J.G., WANG, Y.S., C.C. 2014. Acrylamide-induced apoptosis in rat primary astrocytes and human astrocytoma cell lines. Toxicology In Vitro 4, 562750. http://dx.doi.org/10.1016/j.tiv.2014.01.005

LIU, H., MCPHERSON, B.C., ZHU, X., DA COSTA, M.L., JEEVANANDAM, V., YAO, Z. 2001. Role of nitric oxide and protein kinase C in ACh-induced cardioprotection. American Journal of Physiology-Heart and Circulatory Physiology, 1, 191-197. http://dx.doi.org/10.1152/ajpheart.2001.281.1.H191

LOPACHIN, R.M. 2002. The role of fast axonal transport in acrylamide pathophysiology: mechanism or epiphenomenon? Neurotoxicology, 2, 253-270.

LOPACHIN, R.M., GAVIN, T. 2008. Acrylamide-induced nerve terminal damage: relevance to neurotoxic and neurodegenerative mechanisms. Journal of Agriculture and Food Chemistry, 15, 5994-6003. http://dx.doi.org/10.1021/jf703745t

LOPACHIN, R.M., GAVIN, T. 2012. Molecular mechanism of acrylamide neurotoxicity: lessons learned from organic chemistry. Environmental health perspectives, 12, 1650-1657. http://dx.doi.org/10.1289/ehp.1205432
LOPACHIN, R.M., LEHNING, E.J. 1994 Acrylamide induced distal axon degeneration. A proposed mechanism of action. Neurotoxicology, 15, 247-260.

MEISTER A. 1998. Glutathione metabolism and its selective modification. Journal of biological chemistry, 263, 17205-17208.

NOSHITA, N., SUGAWARA, T., FUJIMURA, M., MORITA-FUJIMURA, Y., CHAN P.H. 2001. Manganese superoxide dismutase affects cytochrome c release and caspase-9 activation after transient focal cerebral ischemia in mice. Journal of Cerebral Blood Flow \& Metabolism, 5, 557-67. http://dx.doi.org/10.1097/00004647-200105000-00010

OHKAWA, H., OHISHI, N., YAGI, K. 1979. Assay for lipid peroxides in animal tissues by thiobarbituric acid reaction. Analytical Biochemistry, 2, 351-8. http://dx.doi.org/10.1016/0003-2697(79)90738-3

PENNISI, M., MALAGUARNERA, G., PUGLISI, V., VINCIGUERRA, L., VACANTE, M., MALAGUARNERA, M. 2013. Neurotoxicity of acrylamide in exposed workers. International Journal of Environmental Research and Public Health, 10, 3843-3854. http://dx.doi.org/10.3390/ijerph10093843

PORTER, A.G., JÄNICKE, R.U. 1999. Emerging roles of caspase-3 in apoptosis. Cell Death and Differentiation, 2, 99-104. http://dx.doi.org/10.1038/sj.cdd.4400476

RIBOLDI, B.P., VINHAS, A.M., MOREIRA, J.D. 2014. Risks of dietary acrylamide exposure: a systematic review. Food Chemistry, 157, 310-322. http://dx.doi.org/10.1016/j.foodchem.2014.02.046

RICE-EVANS, C.A., DIPLOCK, A.T., SYMONS, M.C.R. 1991. Techniques in free radicals research. Amsterdam: Elsevier Science Pub. Co. 22 p. ISBN 0444813047

SHRIVASTAVA, S., UTHRA, C., RESHI, M., SINGH, A., YADAV, D. SHUKLA, S. 2018. Protective effect of hesperetin against acrylamide induced acute toxicity in rats. Indian Journal Of Experimental Biology, 56, 164-170.

SMITH, C.J., PERFETTI, T.A., MULLENS, M.A., RODGMAN, A., DOOLITTLE, D.J. 2000. "IARC group 2B Carcinogens" reported in cigarette mainstream smoke. Food and Chemical Toxicology, 9, 825-848. http://dx.doi.org/10.1016/S0278-6915(00)00164-2

STERN, C.D. 2005. The Chick: A Great Model System Becomes Even Greater Developmental Cell, 8, 9-17. http://dx.doi.org/10.1016/j.devcel.2004.11.018

SUGAWARA, T., NOSHITA, N., LEWÉN, A., GASCHE, Y., FERRANDDRAKE, M., FUJIMURA, M., MORITA-FUJIMURA, Y., CHAN, P.H. 2002. Overexpression of copper/zinc superoxide dismutase in transgenic rats protects vulnerable neurons against ischemic damage by blocking the mitochondrial pathway of caspase activation. Journal of Neuroscience, 1, 209-17. http://dx.doi.org/10.1523/JNEUROSCI.22-01-00209.2002

SUMIZAWA, T., IGISU, H. 2007. Apoptosis induced by acrylamide in $\mathrm{SH}$ SY5Y cells. Archives Of Toxicology, 4, 279-82. http://dx.doi.org/10.1007/s00204-006-0145-6

SUMIZAWA, T., IGISU, H. 2009. Suppression of acrylamide toxicity by carboxyfullerene in human neuroblastoma cells in vitro. Archives of Toxicology, 9, 817-824. http://dx.doi.org/10.1007/s00204-009-0438-7

SÖRGEL, F., WEISSENBACHER, R., KINZIG-SCHIPPERS, M., HOFMANN,

A., ILLAUER, M., SKOTT, A., LANDERSDORFER, C. 2002. Acrylamide: increased concentrations in homemade food and first evidence of its variable absorption from food, variable metabolism and placental and breast milk transfer in humans. Chemotherapy, 48, 267-274. http://dx.doi.org/10.1159/000069715 VON STEDINGK, H., VIKSTRÖM, A.C., RYDBERG, P., PEDERSEN, M. NIELSEN, J.K., SEGERBÄCK, D., KNUDSEN, L.E., TÖRNQVIST, M. 2011. Analysis of hemoglobin adducts from acrylamide, glycidamide, and ethylene oxide in paired mother/cord blood samples from Denmark. Chemical Research of Toxicology, 11, 1957-1965. http://dx.doi.org/10.1021/tx200284u

YAKOVLEV, A.G., OTA, K., WANG, G., MOVSESYAN, V., BAO, W.L., YOSHIHARA, K., FADEN, A.I. 2001. Differential expression of apoptotic protease-activating factor- 1 and caspase- 3 genes and susceptibility to apoptosis during brain development and after traumatic brain injury. The Journal of Neuroscience, $\quad 19, \quad 7439-46 . \quad$ http://dx.doi.org/10.1523/JNEUROSCI.21-1907439.2001

YU, S., ZHAO, X., ZHANG, T., YU, L., LI, S., CUI, N., HAN, X., ZHU, Z. XIE, K. 2005. Acrylamide-induced changes in the neurofilament protein of rat cerebrum fractions. Neurochemical research, 9, 1079-85. http://dx.doi.org/10.1007/s11064-005-7413-3

ZHANG, B., SHAO, H., WANG, X.H., CHEN, X., LI, Z.S., CAO, P., ZHU, D., YANG, Y.G., XIAO, J.W., LI, B. 2017. Acrylamide-induced Subacute Neurotoxic Effects on the Cerebral Cortex and Cerebellum at the Synapse Level in Rats. Biomedical and Environmental Sciences, 6, 432-443. http://dx.doi.org/10.3967/bes2017.057

ZHONG, J., XU, C., GABBAY-BENZIV, R., LIN, X., YANG, P. 2016 Superoxide dismutase 2 overexpression alleviates maternal diabetes-induced neural tube defects, restores mitochondrial function and suppresses cellular stress in diabetic embryopathy. Free Radical Biology and Medicine, 96, 234-44. http://dx.doi.org/10.1016/j.freeradbiomed.2016.04.030 